\title{
Growth and Yield of Schizolobium parahyba var. amazonicum According to Soil Management in Agroforestry Systems: A Case Study in the Brazilian Amazon
}

\author{
Agust Sales ${ }^{1,2, *} \mathbb{C}$, Sílvio Nolasco de Oliveira Neto ${ }^{1}$, Haroldo Nogueira de Paiva ${ }^{1}$, Helio Garcia Leite ${ }^{1}$, \\ Marco Antonio Siviero ${ }^{2}$ and Sabrina Benmuyal Vieira ${ }^{2}$ \\ 1 Department of Forest Engineering, Universidade Federal de Viçosa, Viçosa 36570-900, MG, Brazil; \\ snolasco@ufv.br (S.N.d.O.N.); hnpaiva@ufv.br (H.N.d.P.); hgleite@ufv.br (H.G.L.) \\ 2 Department of Research and Innovation, Grupo Arboris, Dom Eliseu 68633-000, PA, Brazil; \\ marco.siviero@grupoarboris.com.br (M.A.S.); sabrina.benmuyal@grupoarboris.com.br (S.B.V.) \\ * Correspondence: agust.sales@ufv.br
}

check for updates

Citation: Sales, A.; de Oliveira Neto, S.N.; de Paiva, H.N.; Leite, H.G.; Siviero, M.A.; Vieira, S.B. Growth and Yield of Schizolobium parahyba var. amazonicum According to Soil Management in Agroforestry Systems: A Case Study in the Brazilian Amazon. Diversity 2021, 13, 511. https://doi.org/10.3390/ d13110511

Academic Editors: Michael Wink, Francisco E. Fontúrbel and Maureen M. Murúa

Received: 15 September 2021

Accepted: 18 October 2021

Published: 21 October 2021

Publisher's Note: MDPI stays neutral with regard to jurisdictional claims in published maps and institutional affiliations.

Copyright: (c) 2021 by the authors. Licensee MDPI, Basel, Switzerland. This article is an open access article distributed under the terms and conditions of the Creative Commons Attribution (CC BY) license (https:// creativecommons.org/licenses/by/ $4.0 /)$.

\begin{abstract}
Studies on applying of soil management practices in the management of paricá and the effects on growth and yield are essential to auxiliary its cultivation and would allow us to inform management and conservation decisions to reconciliate biodiversity, wellbeing, and sustainable production. This case study aimed to evaluate the growth and yield of paricá at different soil management practices, including consortium with an agricultural production, in the Brazilian Amazon. Paricá was implanted, consorted with soybean in the first year, and maize in the second, in a $5 \times 2 \mathrm{~m}$ spacing. The treatments T1 = subsoiling, basal dressing, top-dressing, inoculation of microorganisms and consortium with soybean/maize were applied. In T2, T3, T4, and T5, we applied the same practices of T1, except subsoiling (T2), basal dressing (T3), top-dressing (T4) and inoculation of microorganisms (T5). T6 was the control, which used none of these practices, including the consortium with soybean/maize. The results indicate that the highest rate of plant survival occurred in T2, while T3 and T4 promoted greater intraspecific competition, compromising the growth in $d b h$ and the yield $\left(\mathrm{m}^{3} \mathrm{ha}^{-1}\right)$ of plants in future ages. Growth in $d b h$ and th and the yield of plants in the soybean/maize consortium period was higher in T2 and T6. In future ages, the $d b h$ and yield of plants demonstrated higher growth trends in T6, T1, and T5. Agroforestry practices of soil management influence the growth and yield of paricá plants. However, there is a tendency for greater growth and yield for paricá plants cultivated in the absence of agroforestry practices for soil management proposed in this case study. When opting for AFS (paricá intercropped with soybean and maize), it is recommended for paricá a subsoiling, fertilization, and inoculation of microorganisms.
\end{abstract}

Keywords: forest fertilization; forest modeling; inoculation of microorganisms; paricá; soil preparation; taungya system; identity test models

\section{Introduction}

Historically, logging in the Amazon has been conducted in an extractive way with negative environmental impacts. In view of the importance of this biome in the international scenario, alternatives have been demanded, such as the sustainable management plan in native forests and, or alternative means of wood production, such as the cultivation of native tree species in monocultures and in agroforestry systems (AFS). Among these tree species, paricá (Schizolobium parahyba var. amazonicum (Huber ex Ducke) Barneby) stands out, A large-sized tree species, belonging to the Caesalpiniaceae family, which occurs in the forests of Amazon [1,2].

Paricá has been the main source of raw material for the industry of veneers and plywood [3,4] with more than 90 thousand hectares of planted area, mainly in the Brazilian Amazon. However, the cultivation of paricá in monocultures and in AFS come up against 
a series of technical, scientific, and operational problems mainly caused by the scarcity of research in the field of plantation forestry.

Planning horizon (clearcutting) of parica both in monoculture and in AFS is generally concentrated between five to seven years, with yield between 10 and $38 \mathrm{~m}^{3} \mathrm{ha}^{-1}$ year $^{-1}$ [4-8]. In monoculture, the square spatial arrangement at $3.5 \mathrm{~m} \times 3.5 \mathrm{~m}$ spacing is usually used [6,9-11]. In AFS, several spatial arrangements were tested for paricá, among them,

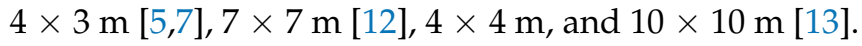

AFS with paricá aim to produce wood in synergy with food production, as well as contributing to ecosystem services such as improving soil fertility, reducing erosion, increasing biodiversity and sequestering carbon $[14,15]$. Due to the closing of the canopy of the AFS, several environmental services are produced, such as the reduction of solar radiation reaching the ground, enabling the creation of a beneficial microclimate, conserving the temperature of the litter and the soil, favoring the maintenance of soil moisture, as well as increased diversity and functionality of macrofauna and edaphic microbiota, contributing to the decomposition of organic residues, favoring nutrient cycling [16-18].

Paricá is cultivated through direct seeding in full sun. It is considered a "rustic" tree species, with good adaptation to soils of low fertility and managed with relatively basic silvicultural practices [8]. In general, for the implementation of paricá, the soil is commonly prepared with plowing and harrowing in the total area, and planting, in most cases, is carried out without the application of fertilizers or following recommendations for other tree species $[8,19]$.

Although paricá responds positively to soil fertilization [20-23], studies show that paricá is able to develop in low fertility soils, which leads most producers, motivated by reducing costs, not to use fertilizers in the implantation and maintenance of the species $[6,8]$. The cost of fertilizers for the paricá represents about $54 \%$ of the total cost of its implementation. The basal dressing and top-dressing are cultural treatments considered essential to improve the development of paricá in the first stages of growth [24-26].

Among the soil preparation methods, plowing/harrowing in total area has been the most used, as it facilitates planting and favors sprouting and root development of the system components $[18,27]$. However, subsoiling in the arboreal component planting line reaches deeper compacted layers than in plowing/harrowing, which can contribute to deeper root development [28,29] and reduce competition for soil growth resources with crops that present greater root volume in the superficial layers [30]. Subsoiling in the paricá planting line in an AFS carried out together with the plowing/harrowing operations in the total area generates an average increase of $70 \%$ in soil preparation costs [31]. The effects of subsoiling on the growth and production of paricá are unknown, indicating a need for research.

Regarding the application of inoculants in the cultivation of paricá, in the study presented by [32], evaluated its growth up to 390 days of age, in Dom Eliseu/PA, Brazil, with application of arbuscular mycorrhizal fungi associated with nitrogen-fixing bacteria. It was observed that the presence of microorganisms significantly stimulated plant growth compared to those not inoculated, indicating that microbial combinations are effective in stimulating the initial growth of paricá, but it is necessary to investigate whether the stimulus occurs at older ages. In general, when the nutrient supply in the soil is relatively high, the effect of the inoculant on plant growth is little noticed and application becomes unnecessary [33-35].

When an AFS is implemented where the main component is the tree species (less wide spacing between trees, similar to monoculture), it is necessary to know the possible effects of soil management practices and intercropping crops on the growth and yield of tree species [6,36]. In AFS, soil management practices should be defined in order to benefit all crops of the system, mainly soil preparation, phytosanitary control and the management of fertilizers and inoculants [37-39]. In addition, the value of the ecosystem services that biodiversity of AFS provides to productive lands has been acknowledged. 
These practices are often referred to as "ecological intensification", which is becoming increasingly common in agricultural production.

Thus, shifting from intensive monoculture or agriculture to a biodiversity-friendly model represents a win-win situation. Based on all this information, it is assumed that studies on applying of soil management practices in the management of paricá and the effects on growth and yield are essential to auxiliary its cultivation and would allow us to inform management and conservation decisions to reconciliate biodiversity, wellbeing, and sustainable production. This case study aimed to evaluate the growth and yield of paricá at different soil management practices, including consortium with an agricultural production.

\section{Materials and Methods}

\subsection{Study Area}

The experiment was carried on the Fazenda Jaspe (Jaspe Farm) (altitude of $160 \mathrm{~m}$ above sea level, $4^{\circ} 0^{\prime} 58^{\prime \prime} \mathrm{S}$ and $47^{\circ} 52^{\prime} 32^{\prime \prime} \mathrm{W}$ ), in the town of Ulianópolis, southeastern state of Pará, Brazil (Figure 1) from 2014 to 2019, being 2014 to 2017 with observed data and 2018 to 2019 with estimated data. Fazenda Jaspe belongs to the Grupo Arboris ${ }^{\circledR}$, an enterprise that works with agriculture and forestry in the Amazon.

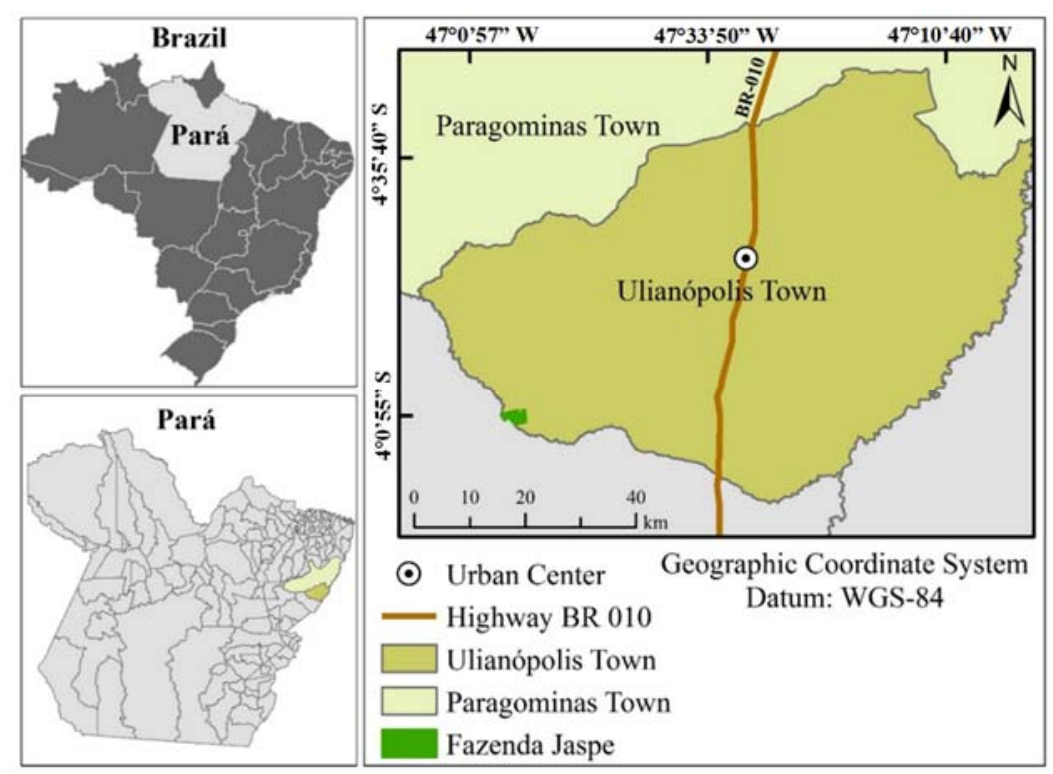

Figure 1. Location of the study area, Fazenda Jaspe, town of Ulianópolis, Pará, Brazil.

The original vegetation of the area is classified as dense tropical submontane forest. The climate is mesothermic and humid, Aw type (Köppen classification). The most common soil is ferralsols with clayey texture, the terrain is even to gently undulated [40-42]. The annual average temperature is $27^{\circ} \mathrm{C}$, with relative humidity oscillating between 42 and $92 \%$. The average annual rainfall is $2000 \mathrm{~mm}$, with rainy season from December to May [43]. Figure 2 presents the data of temperature, precipitation, and water balance for the period of the study (January 2015 through January 2018). 

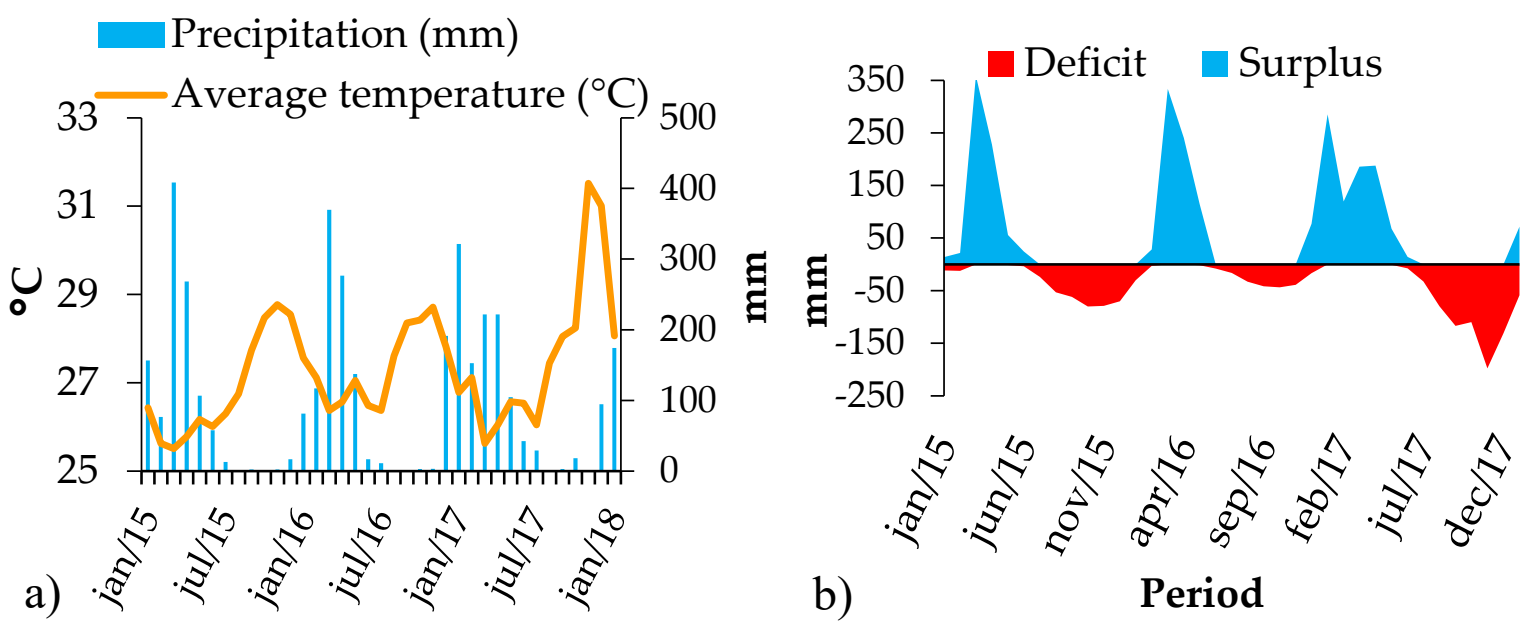

Figure 2. Average temperature and precipitation (a), extract from the water balance (b), during the period from January 2015 to January 2018, in the mesoregion of southeastern of Pará, Brazil.

The management history of the case study area is shown in Table 1.

Table 1. Study area, Fazenda Jaspe, town of Ulianópolis, Pará, Brazil.

\begin{tabular}{ccc}
\hline Year & Components of the System & Area Management \\
\hline 1970 & Area with various species & Removal of native forest \\
1971 & Panicum maximum cv. colonião & Pasture implantation \\
$1971-1979$ & Panicum maximum cv. colonião & Not managed \\
1980 & Brachiaria humidicola & Pasture renewal \\
$1980-2000$ & Brachiaria humidicola & Not managed \\
2001 & Brachiaria brizantha cv. marandu & Pasture renewal \\
$2001-2004$ & Brachiaria brizantha cv. marandu & Not managed \\
$2004-2011$ & Area under restoration process & Fallow \\
$2011-2013$ & Oryza sativa (rice) & Conventional cultivation \\
$2013-2014$ & Glycine max (soybean) & Conventional cultivation \\
\hline
\end{tabular}

In 2015, prior to the implementation of the experiment, chemical and physical analyses of soil were performed at the depth of 0-20 cm, using the methodology proposed by [44] (Table 2).

Table 2. Physical and chemical attributes of soil of the study area, depth of 0-20 cm, Fazenda Jaspe, town of Ulianópolis, Pará, Brazil.

\begin{tabular}{|c|c|c|c|c|c|c|c|c|c|c|}
\hline $\mathrm{pH}$ & MO & $\mathbf{P}$ & $\mathbf{K}$ & $\mathrm{Ca}$ & Mg & Al & $\mathbf{H}+\mathbf{A l}$ & Sand & Silt & Clay \\
\hline $\mathrm{H}_{2} \mathrm{O}$ & dag $\mathrm{kg}^{-1}$ & $\mathrm{mg} \mathrm{dm}^{-3}$ & \multicolumn{5}{|c|}{$\mathrm{cmol}_{\mathrm{c}} \mathrm{kg}^{-1}$} & \multicolumn{3}{|c|}{$\mathrm{g} \mathrm{kg}^{-1}$} \\
\hline 5.01 & 3.39 & 4.33 & 0.24 & 2.23 & 0.81 & 0.47 & 5.70 & 56 & 284 & 660 \\
\hline $\mathbf{N}$ & Mn & $\mathrm{Fe}$ & $\mathrm{Zn}$ & $\mathrm{Cu}$ & $\mathrm{Na}$ & SB & $\mathbf{t}$ & $\mathrm{T}$ & $\mathbf{V}$ & $\mathbf{m}$ \\
\hline$\%$ & \multicolumn{4}{|c|}{$\mathrm{mg} \mathrm{dm}^{-3}$} & \multicolumn{4}{|c|}{$\mathrm{cmol}_{\mathrm{C}} \mathrm{kg}^{-1}$} & \multicolumn{2}{|c|}{$\%$} \\
\hline 0.36 & 33.71 & 55.38 & 9.43 & 5.28 & 0.13 & 2.47 & 2.94 & 8.17 & 27.18 & 15.13 \\
\hline
\end{tabular}

\subsection{Experimental Design}

The AFS evaluated in this experiment were composed of paricá plants planted in intercropping with agricultural crops. In the first year, the paricá plants was intercropped with soybean (Glycine max (L.) Merr.). In the second year, paricá plants was intercropped 
with maize (Zea mays L.). From the third year onwards, there was no more consortium, with only the paricá remaining in the system.

For the installation of the AFS, in October 2014 the soil was prepared to receive the seeds, with plowing/harrowing, application of $2.000 \mathrm{~kg} \mathrm{ha}^{-1}$ of dolomitic limestone (PRNT 95\%) to raise the soil saturation by around 60\%, and pre-planting desiccation with glyphosate $\left(2 \mathrm{~kg} \mathrm{ha}^{-1}\right)$.

Soybeans and maize were cultivated between the lines of paricá plants. The planting of paricá and soybeans took place simultaneously, in January 2015, and maize in February 2016. Paricá was planted in a $5 \times 2 \mathrm{~m}$ spacing with a density of 1000 trees ha ${ }^{-1}$. Soybean (cultivar AN93101) was planted in a spacing of $0.45 \times 0.08 \mathrm{~m}$, occupying $80 \%$ of the area with 278,000 plants ha ${ }^{-1}$. Maize was planted in a spacing of $0.70 \times 0.23 \mathrm{~m}$, occupying $56 \%$ of the area with 62,000 plants ha $^{-1}$.

The planting of parica, in January 2015, was performed via direct sowing with three seeds per hole. The first thinning of plants was performed at 60 days after planting and the second, at 150 days. At 90 days after planting, manual weeding (crowning) was performed around the plants in a radius of $50 \mathrm{~cm}$. The control of ants was carried out with the application of $10 \mathrm{~g}$ of commercial sulfluramide-based bait per $\mathrm{m}^{2}$ of loose soil near the anthill.

The planting of soybean, in January 2015, was carried out together with basal dressing of $400 \mathrm{~kg} \mathrm{ha}^{-1}$ of NPK, in a 02-25-20 formula, in the planting line. 30 days after planting, top-dressing was carried out with foliar application of $7 \mathrm{~L} \mathrm{ha}^{-1}$ of macro and micronutrients $\left(5 \%\right.$ of $\mathrm{N} ; 8 \%$ of $\mathrm{P}_{2} \mathrm{O}_{5} ; 5 \%$ of $\mathrm{K}_{2} \mathrm{O} ; 10 \%$ of $\mathrm{Ca} ; 5.6 \%$ of $\mathrm{Mg} ; 0.4 \%$ of $\mathrm{B} ; 0.2 \%$ of $\mathrm{Cu} ; 10.5 \%$ de $\mathrm{Mn}$ and $1 \%$ of $\mathrm{Zn}$ ). Phytosanitary control was conducted according to the technical recommendation, with periodic applications of insecticides, herbicides, and fungicides. Four months after planting, the soybean harvest was carried out mechanically (April 2015).

In November 2015, the soil between the lines of parica plants was prepared with plowing/harrowing for the planting of maize. In February 2016, maize was planted together with basal dressing of $200 \mathrm{~kg} \mathrm{ha}^{-1}$ of NPK, in 10-28-20 formula, in the planting line. Top-dressing was carried out 30 days after planting, with $200 \mathrm{~kg} \mathrm{ha}^{-1}$ of NPK in 20-00-20 formula, in the planting line. Phytosanitary control was conducted according to technical recommendation, with periodic applications of insecticides, herbicides, and fungicides. Five months after planting, the maize harvest was carried out mechanically (June 2016).

We defined six treatments, combining the soil management practices (applied only once) used in the implantation and for the conduction of the species, with 1 hectare destined to each treatment:

$\mathrm{T} 1$ = subsoiling + basal dressing + top-dressing + inoculation of microorganisms + consortium with soybean/maize;

$\mathrm{T} 2$ = without subsoiling + basal dressing + top-dressing + inoculation of microorganisms + consortium with soybean/maize;

T3 = subsoiling + without basal dressing + top-dressing + inoculation of microorganisms + consortium with soybean/maize;

$\mathrm{T} 4$ = subsoiling + basal dressing + without top-dressing + inoculation of microorganisms + consortium with soybean/maize;

T5 = subsoiling + basal dressing + top-dressing + without inoculation of microorganisms + consortium with soybean/maize;

T6 = without subsoiling + without basal dressing + without top-dressing + without inoculation of microorganisms + without a consortium with soybean or maize.

The subsoiling was conducted, in January 2015, in the planting line of parica plants with a subsoiler implement with a unique stem, regulated to reach the maximum depth of $50 \mathrm{~cm}$. Basal dressing was carried out together with subsoiling, by applying $300 \mathrm{~kg} \mathrm{ha}^{-1}$ of NPK to the 10-30-10 formula in the planting line, with the aid of the implement coupled to the subsoiler. In the T2 treatment, the basal dressing was carried out simultaneously to the 
sowing of paricá, in January 2015, with manual application of $0.3 \mathrm{~kg} \mathrm{plant}^{-1}$ of NPK, in the aforementioned formula.

Concurrently to the planting of paricá, it was manually applied $30 \mathrm{~g} \mathrm{hole}^{-1}$ of inoculant, distant $10 \mathrm{~cm}$ from the hole. The inoculant is a result of the combination of arbuscular mycorrhizal fungi (Glomus clarum, Glomus intraradices and Glomus etunicatum) associated with nitrogen-fixing bacteria (Rhizobium sp). The cultivation and concentration of the inoculant followed the recommendation of [33]. A total of 60 days after planting, manual operations of top-dressing were performed, with the application of $200 \mathrm{~g}^{\text {hole }}{ }^{-1}$ of ammonium sulfate $\left(\left(\mathrm{NH}_{4}\right)_{2} \mathrm{SO}_{4}\right)$, in a lateral hole, distant $20 \mathrm{~cm}$ from the principal hole.

Five plots of $400 \mathrm{~m}^{2}$, each containing 40 trees, were installed for each treatment, being evaluated at $8,22,36,48$ and 60 months of age the growth in diameter at breast height $(d b h)$ and total height $(t h)$ and the yield. Measurements of $d b h$ and th of all trees were performed in each plot at 8, 22 and 36 months of age, as well as survival analysis (\%), and estimates were generated for 48 and 60 months for growth trends in $d b h$, th and yield.

\subsection{Modeling of Growth in Diameter and Height}

Growth in diameter and height was projected as a function of age for 48 and 60 months, the latter refers to the age at which paricá trees are usually harvested. It was adjusted the model [45]:

$$
Y_{2}=Y_{1}+\exp ^{\left(\beta_{0}+\frac{\beta_{1}}{I_{2}}\right)}-\exp ^{\left(\beta_{0}+\frac{\beta_{1}}{I_{1}}\right)}+\varepsilon
$$

where $Y_{2}$ refers to height $(\mathrm{m})$ or diameter $(\mathrm{cm})$ at future age, $Y_{1}$ height $(\mathrm{m})$ or diameter $(\mathrm{cm})$ in current age, $I_{1}$ current age, in months, $I_{2}$ future age, in months, $\beta_{0}$ and $\beta_{1}$ model coefficients, and $\varepsilon$ random error. This model was adjusted by the least squares, using Gauss-Newton algorithms through the Stata $12{ }^{\circledR}$ software system [46].

\subsection{Sampling and Adjustment of Volumetric Model}

At 36 months, the distribution of diameters in classes with amplitude of $2 \mathrm{~cm}$ was used to define the sample-trees to be harvested for volume estimation, six sample-trees per class. Total height and diameter with bark were measured in each sample tree, at the heights of $0,1,2,4,6 \mathrm{~m}$, until the minimum diameter, with bark of $4 \mathrm{~cm}$. The volume of wood with bark of each tree was obtained using the Smalian formula, with previous interpolation in sections of 0,1 [47], with $n=100$, according to:

$$
V=\frac{h}{4^{n}}\left(\left(\frac{2^{2 n+1}+1}{6}\right) g_{1}+\left(\frac{2^{2 n+1}+1}{6}\right) g_{2}+\left(\frac{2^{2 n+1}-1}{3}\right) \sqrt{g_{1} g_{2}}\right)
$$

where $V$ refers to the trunk volume in $\mathrm{m}^{3}, h$ trunk length in $\mathrm{m}, n$ number of linear interpolations, and $g_{i}$ sectional area $\frac{\pi D_{i}^{2}}{40000}$, in $\mathrm{m}^{2}$.

The Schumacher and Hall [48] model was adjusted:

$$
V=\beta_{0} d a p^{\beta_{1}} h t^{\beta_{2}}+\varepsilon
$$

where $V$ is the volume in $\mathrm{m}^{3}$, dap is the diameter at breast height in $\mathrm{cm}, h t$ is the total height in $\mathrm{m}, \beta_{0}, \beta_{1}$ and $\beta_{2}$ are the model parameters, and $\varepsilon$ is the random error.

At each age, the volume was obtained by means of the equation adjusted by the volumetric model already mentioned, using the estimated values of $d b h$ and th. Yield $\left(\mathrm{m}^{3} \mathrm{ha}^{-1}\right)$ was calculated by the sum of the volumes of the surviving trees in each plot multiplied by $10,000\left(\mathrm{~m}^{2}\right)$ and divided by the area $\left(400 \mathrm{~m}^{2}\right)$ of the plot. Graphs were drawn up with the growth curves in $d b h$, th, and yield from 8 to 60 months of age.

\subsection{Evaluation Criteria of Equations}

The following statistics were estimated to evaluate the adjusted equations for $d b h$, th and volume: 
(a) adjusted coefficient of determination $\left(\hat{R}^{2}\right)$ [49]:

$$
\dot{R}^{2}=\text { QMres/QMtotal }
$$

where $Q M r e s$ is the residual variance and QMtotal is the corrected total variance.

(b) Bias [50]:

$$
\text { Bias }=\frac{\sum_{i=1}^{n}\left(\hat{y}_{i}-y_{i}\right)}{n}
$$

(c) residual standard error $\left(S_{y \cdot x \%}\right)[51]$ :

$$
S_{y \cdot x \%}= \pm \frac{\sqrt{\frac{\sum_{i=1}^{n}\left(y_{i}-\hat{y}_{i}\right)^{2}}{n-p-1}}}{\bar{y}} \cdot 100
$$

where $y_{i}$ is the observed value for the dependent variable, $\hat{y}_{i}$ is the estimated value for the dependent variable, $\bar{y}_{i}$ is the mean of the observed values for the dependent variable, $n$ is the number of observations, $p$ is the number of model coefficients, $n$ is the number of observations of $y$.

For the equations adjusted for volume, the estimated values were related to the observed and the frequency distributions per class of relative error percentages-RE $\%$.

$$
R E=\frac{\left(\hat{y}_{i}-y_{i}\right)}{y_{i}} .100
$$

where $\hat{y}_{i}$ is the estimated value for the dependent variable, and $y_{i}$ is the observed value for the dependent variable.

\subsection{Statistical Analysis}

Identity test models [52] were applied to compare the equations adjusted for yield $\left(\mathrm{m}^{3} \mathrm{ha}^{-1}\right)$ projected at 60 months of age by the [49] model for each treatment in program Microsoft Office Excel 2021 ${ }^{\circledR}$ (Table 3).

Table 3. Analysis of variance for the identity test models aiming to compare [49] model adjusted to different datasets (treatments) *.

\begin{tabular}{ccccc}
\hline FV & GL & SQ & QM & F \\
\hline Parameters of complete model & $p_{1}$ & SQParC & & \\
\hline Parameters of reduced model & $p_{2}$ & SQParR & & \\
\hline Reduction due to $\mathrm{H}_{0}$ & $p_{1}-p_{2}$ & SQRH $_{0}$ & QMRH $_{0}$ & QMRH $_{0} /$ QMRes \\
\hline Residual & $n-p_{1}$ & SQRes & QMRes & \\
\hline Total & $n$ & SQTnc & & \\
\hline
\end{tabular}

${ }^{*} p$-Value $=$ rejection area of $\mathrm{H}_{0}$ for F statistical. $\mathrm{QMRH}_{0} / \mathrm{QMRes} \sim \mathrm{F} \alpha$ (PC-PR e n-PC g.l.). SQTnc $=Y^{\prime} Y=\sum_{h=1}^{H} \sum_{h=1}^{n H} y_{h i}^{2}$, with $n$ degrees of freedom, being $n_{h}$ the number of observations of $Y$ in the dataset of treatment $h$. SQParC $=\sum_{h=1}^{H} \hat{\beta}_{h}{ }_{h} X^{\prime}{ }_{h} Y_{h}=\sum_{h=1}^{H}\left[y^{\prime}{ }_{h} y_{h}-\left(y_{h i}-y_{h i c}\right)^{2}\right]$, being $y \hat{h i c}$ the estimated value of $Y$ for $i$ observation of data set of the treatment $h$, using the complete model. The number of degrees of freedom is $p_{1}$, and is the number of coefficients in the complete model. SQParR $=\sum_{h=1}^{H} \hat{\beta}^{\prime}{ }_{h} X_{h}{ }_{h} Y_{h}=\sum_{h=1}^{H}\left[y_{h}^{\prime} y_{h}-\left(y_{h i}-y \hat{h i r}\right)^{2}\right]$, being $y_{h i r}$ he estimated value of $Y$ for $i$ observation of data set of the treatment $h$, using the reduced model. The number of degrees of freedom is $p_{2}$, and is the number of coefficients in the reduced model. SQRH ${ }_{0}=\mathrm{SQParC}-\mathrm{SQParcR}$, with $p_{1}-p_{2}$ degrees of freedom. SQRes $=\mathrm{SQTnc}-\mathrm{SQParC}$, with $n-p_{1}$ degrees of freedom.

\section{Results}

The survival rate (\%) of plants of paricá at eight months indicated rates between 97 and $99 \%$ (Figure 3). The highest survival rate of plant (92\%) for the age of 22 months was verified in T2, and the lowest rates in T1 and T6 (79 and 79\%, respectively). At 36 months, it was observed reduced survival rates of paricá plants in the treatments. The highest survival rates were found in $\mathrm{T} 2$ and $\mathrm{T} 4$, and the lowest, in T1 and T5. 


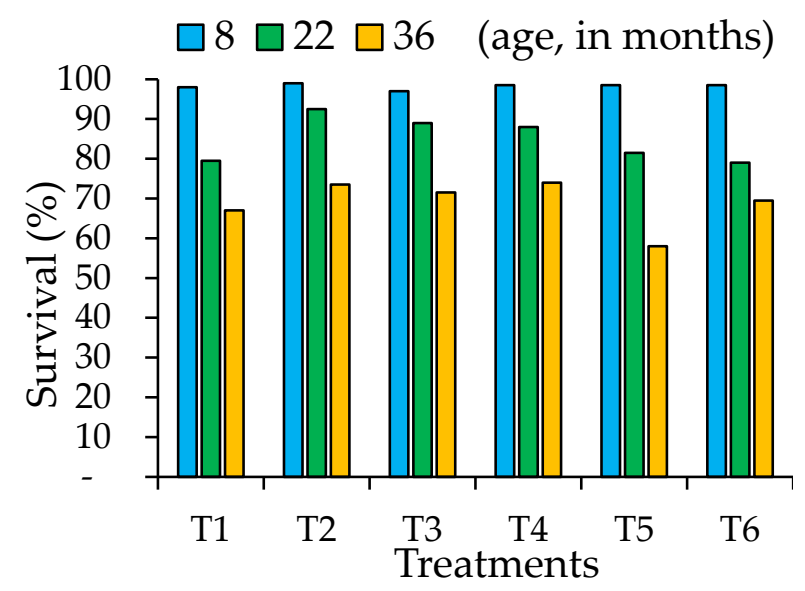

Figure 3. Survival (\%) of trees of paricá at 8,22 , and 36 months of age, submitted to soil management practices.

In the six treatments, the equations adjusted for $d b h$ and th present satisfactory statistics $\left(\hat{R}^{2}\right.$, Bias e Sy. $\left.x_{\%}\right)$. The best adjustments for $d b h$ and th were obtained in the treatments T2, $\mathrm{T} 3$, and T6, with the highest $\hat{R}^{2}$ and value lowest rate of Bias and Sy. $x_{\%}$, followed by the plants of the treatments $\mathrm{T} 1, \mathrm{~T} 4$, and $\mathrm{T} 5$. All coefficients of the equations were significant $(p<0.05)$ (Figure 4$)$.

Growth in $d b h$ of paricá plants during the consortium period with soybean/maize (18 first months) was higher in T2, compared to the other treatments $(p<0.05)$. The lowest values were observed in plants of the treatments T1 and T5 (Figure 4a). However, with the projection of $d b h$ growth in a future age, there was a trend of higher growth for plants of T6 and growth recovery for plants in the treatments T1 and T5, whose growth values were similar to those of the plants in T2. Similar performance was observed for the growth in th (Figure $4 b$ ).

However, decreased growth trend in th in future ages is observed for the T2 plants. Higher values were observed for $d b h$, th, and yield, during the consortium period with soybean/maize, with the application of T2. However, the projection of growth in future ages of the plants submitted to T2 shows a trend of early stagnation of growth and lower values of $d b h$, th and yield, in comparison to the other treatments, with the exception of plants submitted to T4, which showed the same tendency as the plants in T2. The plants in treatments $\mathrm{T} 1$ and $\mathrm{T} 5$ presented different behavior from those in T2, with lower growth in $d b h$ and th and yield, during the consortium period with soybean/maize, and trend of growth recovery in the future ages.

For estimates of volume, we can highlight as more precise adjustments the equations involving the treatments T2, T3 and T4, with higher values of $\hat{R}^{2}$ and the lowest of Bias and Sy. $x_{\%}$, in comparison to the other treatments. All coefficients of the equations were significant $(p<0.05)$ (Figure $4 c)$. For yield of paricá plants during the period of the soybean/maize consortium (Figure 4c), the performance was similar to that observed in plant growth in $d b h$ and th (Figure 4). In the projection of growth in volume for future ages, there was a trend of higher growth for plants of T6, followed by plants of the treatments T1, T3 and T5. In T2, a greater tendency of plant growth stagnation was observed for future ages. 
$\begin{array}{lllllllll}\beta_{0} & \beta_{1} & \bar{R}^{2} & \text { Bias } & \text { Sy.x\% } & \beta_{0} & \beta_{1} & \bar{R}^{2} & \text { Bias } \quad \text { Sy.x\% }\end{array}$

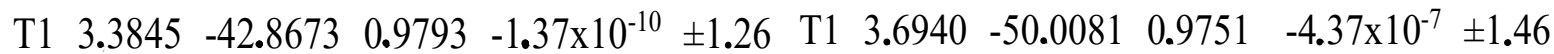

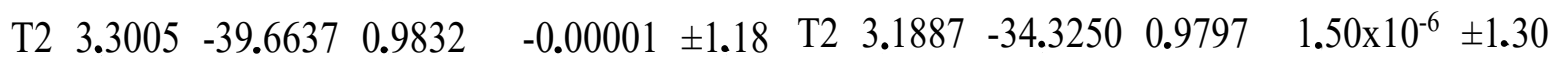

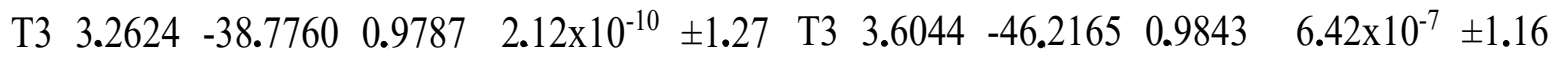

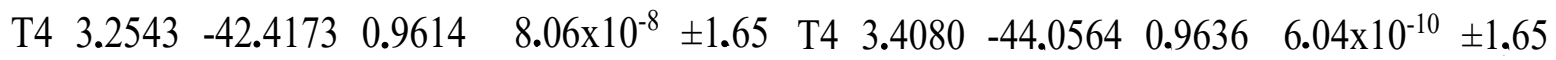

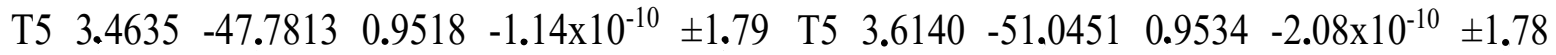

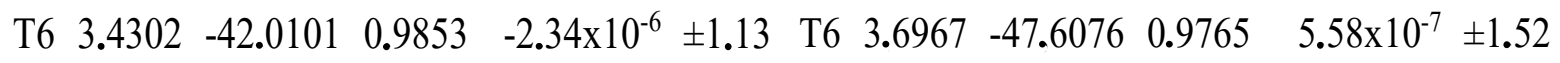

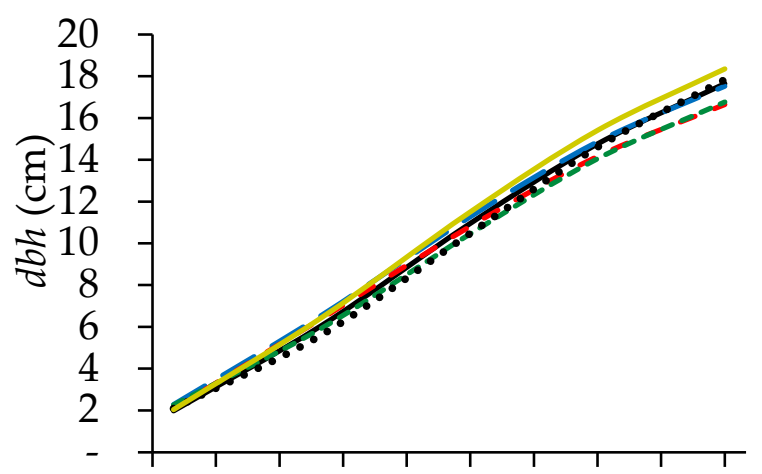

a) $\begin{array}{llllllllll}6 & 12 & 18 & 24 & 30 & 36 & 42 & 48 & 54 & 60\end{array}$ Age (months)

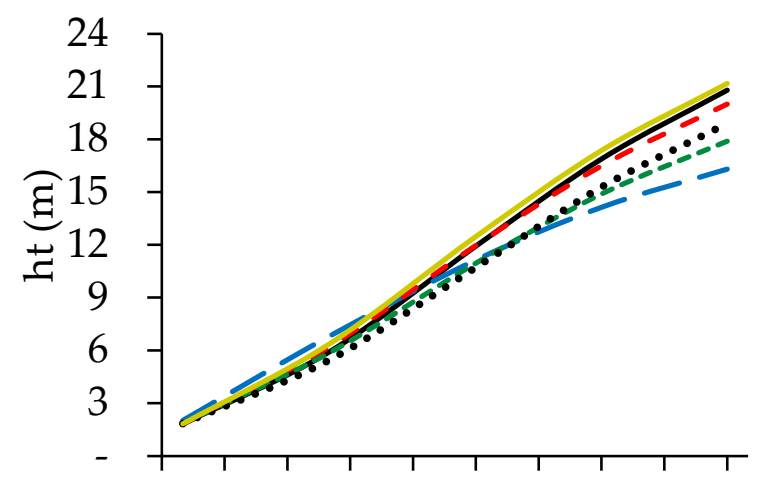

b) $\begin{array}{llllllllll}6 & 12 & 18 & 24 & 30 & 36 & 42 & 48 & 54 & 60\end{array}$

Age (months)

$\begin{array}{llllll}\beta_{0} & \beta_{1} & \beta_{2} & \bar{R}^{2} & \text { Bias } & \text { Sy.x\% }\end{array}$

$\begin{array}{lllllll}\mathrm{T} 1 & -9.5456 & 1.7269 & 1.0367 & 0.9876 & -0.00004 & \pm 0.37\end{array}$

$\begin{array}{llllllll}\text { T2 } & -9.5187 & 1.4225 & 1.3444 & 0.9905 & -0.00007 & \pm 0.63\end{array}$

$\begin{array}{lllllll}\text { T3 } & -9.3753 & 1.5760 & 1.1398 & 0.9956 & 0.00015 & \pm 1.31\end{array}$

$\begin{array}{llllllll}\text { T4 } & -9.5905 & 1.3702 & 1.4067 & 0.9934 & -0.00007 & \pm 0.61\end{array}$

$\begin{array}{lllllll}\text { T5 } & -10.0170 & 1.0260 & 1.9236 & 0.9590 & -0.00089 & \pm 7.99\end{array}$

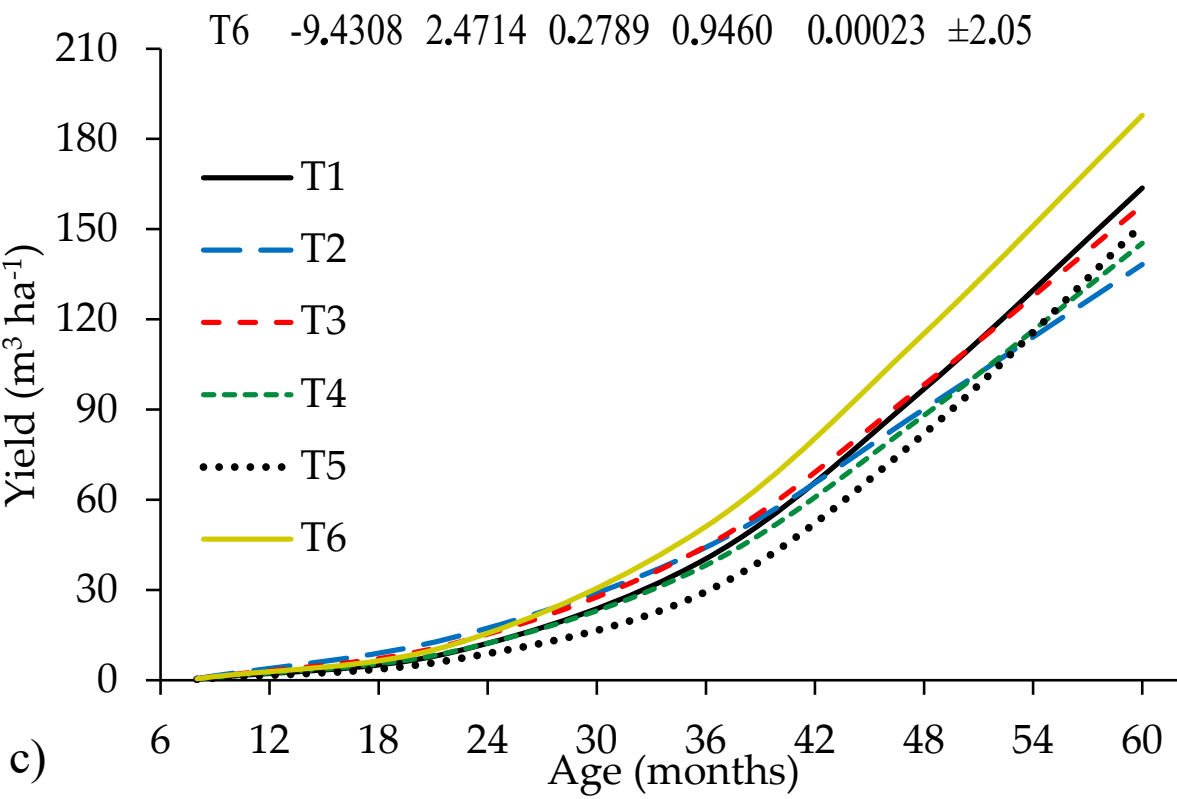

Figure 4. Estimates and growth trends in diameter at breast height $(d b h)(\mathbf{a})$ total height $(t h)(\mathbf{b})$ and Yield $\left(\mathrm{m}^{3} \mathrm{ha}^{-1}\right)(\mathbf{c})$ of trees of paricá, submitted to soil management practices. $\beta_{0}, \beta_{1}$ and $\beta_{2}=$ regression coefficients; $\hat{R}^{2}=$ adjusted coefficient of determination; Bias; Sy. $x_{\%}=$ residual standard error. Trees and species destined for the sale of standing wood by the dbh class center and market value group for the criteria and control treatments, forest management area of Fazenda Shet, Dom Eliseu, State of Pará, Brazil. 
Identity test models performed for comparisons, two-to-two, of the equations adjusted for yield $\left(\mathrm{m}^{3} \mathrm{ha}^{-1}\right)$ projected at 60 months of age for each treatment, applied to combinations of treatments $\mathrm{T} 1+\mathrm{T} 3, \mathrm{~T} 3+\mathrm{T} 4$ and for all combinations with T5 and T6, indicates differences $(p<0.05)$ between the combined treatments. Therefore, it is appropriate to make the adjustment of the separate volumetric model for the data set of each treatment. On the other hand, the non-significance $(p>0.05)$ to combinations of treatments $\mathrm{T} 1+\mathrm{T} 2$, $\mathrm{T} 1+\mathrm{T} 4, \mathrm{~T} 2+\mathrm{T} 3$, and T2 + T4 shows that these combined treatments do not differ and that it is more appropriate to use the reduced model (Table 4).

Table 4. $p$-value and F-test (between parenthesis) calculated for comparisons, two-to-two, of the equations adjusted for yield $\left(\mathrm{m}^{3} \mathrm{ha}^{-1}\right)$ projected at 60 months of age by [49] model for each treatment.

\begin{tabular}{ccccccc}
\hline Treatment $^{*}$ & $\mathbf{1}$ & $\mathbf{2}$ & $\mathbf{3}$ & $\mathbf{4}$ & $\mathbf{5}$ & $\mathbf{6}$ \\
\hline 1 & & 0.0576 & $\mathbf{0 . 0 0 1 3}$ & 0.2595 & $\mathbf{0 . 0 3 4 3}$ & $\mathbf{0 . 0 4 0 2}$ \\
\hline 2 & $(2.65)$ & & 0.5341 & 0.0801 & $\mathbf{0 . 0 4 9 8}$ & $\mathbf{0 . 0 0 0 7}$ \\
\hline 3 & $\mathbf{( 6 . 0 0 )}$ & $(0.74)$ & & $\mathbf{0 . 0 0 1 7}$ & $\mathbf{0 . 0 2 1 1}$ & $\mathbf{0 . 0 0 0 7}$ \\
\hline 4 & $(1.38)$ & $(2.38)$ & $\mathbf{( 5 . 8 3 )}$ & & $\mathbf{0 . 0 1 0 8}$ & $\mathbf{0 . 0 0 1 9}$ \\
\hline 5 & $\mathbf{( 3 . 1 1 )}$ & $(\mathbf{2 . 7 9 )}$ & $\mathbf{( 3 . 5 3 )}$ & $\mathbf{( 4 . 1 5 )}$ & & $\mathbf{0 . 0 0 0 1}$ \\
\hline 6 & $\mathbf{( 2 . 9 7 )}$ & $\mathbf{( 6 . 7 1 )}$ & $\mathbf{( 6 . 7 2 )}$ & $\mathbf{( 5 . 7 8 )}$ & $\mathbf{( 1 1 . 7 7 )}$ & \\
\hline${ }^{*}$-value $(<0.05)$ in bold. & & & & & &
\end{tabular}

\section{Discussion}

Square spatial arrangements $(3.5 \times 3.5 \mathrm{~m})$ are the most used for monocultures of paricá [6,9-11], and AFS $(4 \times 4 \mathrm{~m}, 7 \times 7 \mathrm{~m}$ and $10 \times 10 \mathrm{~m})[12,13]$. However, in this case study, a rectangular spatial arrangement $(5 \times 2 \mathrm{~m})$ was used, that is, a greater distance between rows of paricá plants to enable the use of agricultural machinery, and a smaller distance between plants in the planting row to expand the population of parica. Paricá respond to the spacing effect [4,5] and, therefore, in this case study, the relatively smaller spacing $(2 \mathrm{~m})$ between plants in the planting line may have anticipated competition between plants up to 22 months of age, since a reduction in the survival rate of plants of all treatments was observed.

Studies presented by $[19,53]$ analyzed the behavior of paricá tree in different spacings and verified higher growth rates in $d b h$, th and volume in larger spacing $(4 \times 3 \mathrm{~m}$ and $4 \times 4 \mathrm{~m})$, compared to smaller spacings $(1.5 \times 1.5 \mathrm{~m}, 3 \times 2 \mathrm{~m}, 3 \times 3 \mathrm{~m}$ and $4 \times 2 \mathrm{~m})$. In the study presented by [54] observed that paricá trees presented larger quadratic diameters for larger spacings, in contrast to the findings for smaller spacings. The author points out that, for the age of 24 months, the diameter of the trees in the smallest spacing did not statistically differ from the larger spacings. Significant influence started at 36 months, due to competition.

The projection of higher growth for T6 may be due to the paricá's ability to develop in low fertility soils and with basic silvicultural practices [8]. The dense arrangement of crops in the AFS may have generated competition between agricultural and arboreal plants, especially in the first years of the AFS. However, plants tend to show growth recovery after intercropping, as shown by [55] in the study in which plants of Tectona grandis $(4 \times 2 \mathrm{~m}$ spatial arrangement) in taungya system with maize, grew less initially, when compared to plants in pure stands, but showed a trend of recovery of growth with the exit of the agricultural component of the system, at 18 months. A study presented by [5] reinforces that paricá cultivated in an AFS with soybean/maize in the initial four years presented production similar to that of paricá in pure stands, from the fifth year.

In the present case study, the plants of paricá in the treatments with lower survival rates presented higher $d b h$, th, and yield. It is important to emphasize that, in the cultivation of paricá for the production of veneers and plywood, it is appropriate to conduct the stands in order to obtain trees of larger diameters [3,56]. In studies of $[3,57]$, in which the yield of 
veneer and plywood production from paricá wood was evaluated, the diameter was the main factor for the yields of high-quality veneers.

However, the decreased survival rate of plants compromises the final productivity of the stands. With the objective of stimulating the maximum growth of the individuals and obtaining superior wood for the industry, it is suggested that thinning be performed or that the spatial arrangement be revised, concomitantly with adequate soil management. Paricá develops under different arrangements and edaphic and climatic conditions [18,58,59]. The study presented by [6], highlights that, with proper management, paricá can present similar or superior growth in AFS, when compared to pure stands.

The present study shows little response of paricá in relation to the soil management practices adopted. Studies performed by $[6,8,54]$ reported that paricá is considered a "rustic" species, for its relatively easy management and its low response to agroforestry combinations [7]. However, the good level of soil fertility (Table 2), a likely consequence of previous crops (Table 1), may explain the absence of responses to soil management practices in the growth and yield of paricá plants in the ages evaluated.

In other studies, the paricá responded to fertilization [20-23], but soil fertility must be analyzed case by case, respecting local particularities, for fertilizer recommendations, since fertilization can be reduced or even unnecessary, according to the supply of nutrients in the soil. Regarding the use of inoculants, their application has been more effective in low fertility soils, since they increase the surface area of the roots and absorption capacity of water and nutrients, which enhances the growth and survival rates of plants [26,59]. When the supply of nutrients in the soil is relatively high, the effect of inoculant on plant growth is little perceived, and application becomes unnecessary [34-36]. In this case study, it is not known whether the use of intercropping with agricultural crops can justify the non-response to fertilization.

Although T6 has not received the evaluated soil management practices, the entire area of this case study was prepared with plowing/harrowing and application of dolomitic limestone (conventional soil management practices for the cultivation of paricá) before applying the treatments (T1-T6), which provided good growing conditions, moreover, the result of the soil analysis carried out before the implementation of the experiment showed good chemical and fertility conditions for the cultivation of parica (Table 2).

It is important to highlight that subsoiling and plowing/harrowing are efficient when carried out in soils with high levels of compaction [60]. Plant roots that grow on soils with compaction problems do not adequately utilize the available nutrients, since the development of new roots that absorb water and nutrients is impaired. In addition, the amount of oxygen in the rhizosphere may hinder metabolic processes [29,31].

Regarding the results of identity test models, it was observed compatibility with the adjustment levels of the equations adjusted for yield $\left(\mathrm{m}^{3} \mathrm{ha}^{-1}\right)$ projected at 60 months of age for each treatment, verified in the statistics $\hat{R}^{2}$, Bias and $S y . x \%$, besides the distribution of RE\%. It demonstrates the reliability of test indication for the use or not of the reduced model [61]. The compatibility between the test and the statistics of the adjustments of the volume equations refers to the higher values of $\hat{R}^{2}$, lower values of Bias and Sy.x\% and more homogenous and balanced distribution of RE\% observed in the statistics of the treatment T1, T2, T3 and T4, compared to the values found in the statistics of the treatments $\mathrm{T} 5$ and $\mathrm{T} 6$.

Similarly to other tree species, it is understood that greater success in paricá cultivation is achieved when adequate soil management practices are adopted. This project of sampling and composition of treatments should be improved in future studies, with evaluation of other soil management practices, including treatment without intercropping with soybean/maize, in order to reduce the chances of masking the results of the experiment and providing more conclusions concrete. In this context, new studies should focus on methods of soil preparation, dosages, and times of application of fertilizers and inoculants, in addition to consortia with agricultural or tree crops, also considering local criteria and peculiarities. 


\section{Conclusions}

Soil management practices in agroforestry systems influence the growth and yield of paricá plants. However, there is a tendency for greater growth and yield for plants cultivated in the absence of soil management practices proposed in this case study.

When opting for AFS, paricá intercropped with soybean (first year) and maize (second year), it is recommended for paricá a subsoiling, fertilization, and inoculation of microorganisms.

New spatial arrangements and spacing must be tested for their technical feasibility for use in the intercropping of paricá with agricultural crops and other soil management practices.

Author Contributions: Conceptualization, M.A.S. and S.B.V.; methodology, A.S., M.A.S., S.N.d.O.N., H.N.d.P. and H.G.L.; analysis, A.S., S.N.d.O.N., H.G.L. and S.B.V.; resources, A.S. and S.N.d.O.N.; data curation, A.S., S.N.d.O.N., H.N.d.P. and H.G.L.; writing—original draft preparation, A.S., M.A.S. and S.B.V.; writing-review and editing, A.S., S.N.d.O.N., H.N.d.P., H.G.L., M.A.S. and S.B.V. All authors have read and agreed to the published version of the manuscript.

Funding: This research received no external funding.

Institutional Review Board Statement: Not applicable.

Data Availability Statement: Not applicable.

Acknowledgments: The authors are thankful to the Universidade Federal de Viçosa, Grupo Arboris and Conselho Nacional de Desenvolvimento Científico e Tecnológico-CNPq, for the granting of master's scholarships and productivity in research.

Conflicts of Interest: The authors declare no conflict of interest.

\section{References}

1. De Souza, C.R.; de Rossi, L.M.B.; de Azevedo, C.P.; Vieira, A.H. Paricá: Schizolobium parahyba var. amazonicum (Huber $\times$ Ducke) barneby. Embrapa Amaz. Ocident.-Circ. Técnica 2003, 12. Available online: https://core.ac.uk/download/pdf/15430772.pdf (accessed on 30 August 2019).

2. Da Silva, C.B.R.; dos Santos Junior, J.A.; Araújo, A.J.C.; Sales, A.; Siviero, M.A.; Andrade, F.W.C.; Castro, J.P.; de Figueiredo Latorraca, J.V.; de Lima Melo, L.E. Properties of juvenile wood of Schizolobium parahyba var. amazonicum (Paricá) under different cropping systems. Agrofor. Syst. 2020, 94, 583-595. [CrossRef]

3. Da Silva, G.F.; de Mendonça, A.R.; Hoffmann, R.G.; Zaneti, L.Z.; Chichorro, J.F.; Ferreira, R.L.C. Rendimento em laminação de madeira de paricá na região de paragominas, pará. Ciência Florest. 2015, 25, 447-455. [CrossRef]

4. Da Silveira, R.; da Silva, G.F.; Binoti, D.H.B.; Manhães, L.D.P.; Gonçalves, A.F.A.; Aragão, M.D.A. Custos da produção de madeira de paricá na região de Paragominas, PA. Pesqui. Florest. Bras. 2017, 37, 597-604. [CrossRef]

5. Silva, A.R.; Sales, A. Crescimento e produção de paricá em diferentes idades e sistemas de cultivo. Adv. For. Sci. 2018, 5, 231-235. [CrossRef]

6. Rodrigues, P.G.; Ruivo, M.D.L.P.; Piccinin, J.L.; Jardim, M.A.G. Contribuição dos atributos químicos do solo no desenvolvimento vegetativo do paricá em diferentes sistemas de cultivo. Ciência Florest. 2016, 26, 59-68. [CrossRef]

7. Cordeiro, I.M.C.C.; de Barros, P.L.C.; Lameira, O.A.; Gazel Filho, A.B. Avaliação de plantios de paricá (Schizolobum parahyba var. amazonicum (Huber ex Ducke) Barneby de diferentes idades e sistemas de cultivo no município de aurora do PARÁ-PA (Brasil). Ciência Florest. 2015, 25, 679-687. [CrossRef]

8. AMATA. Revisão Sobre Paricá: Schizolobium Amazonicum Huber Ex Ducke; AMATA S/A-Inteligência da Floresta Viva: São Paulo, Brazil, 2009.

9. Galeão, R.R.; Marques, L.C.T.; Yared, J.A.G.; Ferreira, C.A.P. Paricá (Schyzolobium amazonicum Huber): Espécie florestal de uso múltiplo com alto potencial para reflorestamento na amazônia brasileira. Rev. Ciênc. Agrár. Amaz. J. Agric. Environ. Sci. 2005, 44, 157-162.

10. Carvalho, P.E.R. Paricá (Schizolobium amazonicum). Colombo Embrapa Florestas 2007, 142, 8.

11. Santos, I.S.; Salim, S.; Pereira, P.C.G. Caracterização do reflorestamento de paricá na microrregião de paragominas-PA. Rev. Agroecossistemas 2018, 10, 145-158. [CrossRef]

12. Silva, A.; Brito, S.; Silva, I.; Paula, M.; Sousa, B.S. Viabilidade econômica em sistema agroflorestal no município de Santa Izabel do Pará, PA. Enciclopédia Biosf. 2018, 15. [CrossRef]

13. Pompeu, G.d.S.d.S. Sistemas Agroflorestais: Manejo, Sustentabilidade e Percepção Ambiental dos Agricultores de Tomé-Açu, Pará, Brasil. Ph.D. Dissertation, Universidade Federal Rural da Amazônia, Belém, Pará, Brazil, 2017. 
14. Garcia, L.T.; Paulus, L.A.R.; Fernandes, S.S.L.; Arco-Verde, M.F.; Padovan, M.P.; Pereira, Z.V. Viabilidade financeira de sistemas agroflorestais biodiversos no Centro Oeste Brasileiro. Res. Soc. Dev. 2021, 10, 47210413682. [CrossRef]

15. Steenbock, W.; Vezzani, F.M.; Coelho, B.H.D.S.; da Silva, R.O. Agrofloresta agroecológica: Por uma (re)conexão metabólica do humano com a natureza. Guaju 2021, 6, 47-70. [CrossRef]

16. Gomes, L.; Bianchi, F.; Cardoso, I.; Fernandes, R.; Filho, E.F.; Schulte, R. Agroforestry systems can mitigate the impacts of climate change on coffee production: A spatially explicit assessment in Brazil. Agric. Ecosyst. Environ. 2020, 294, 106858. [CrossRef]

17. Fernandes, S.S.L.; Santiago, E.F.; Padovan, M.P.; Carneiro, L.F.; Filho, E.D.M.V. Serviços ambientais culturais e de suporte: Percepção por agricultores familiares em sistemas agroflorestais do Brasil e Costa Rica. Res. Soc. Dev. 2020, 9, 11691210783. [CrossRef]

18. Silva, A.R.; Sales, A.; Veloso, C.A.C.; Carvalho, E.J.M. Efeito do cultivo de paricá em sistemas integração lavoura-pecuária-floresta sobre as propriedades físicas e teor de matéria orgânica de um latossolo amarelo. Tecnol. Ciênc. Agropecuária 2016, 10, 53-61.

19. Rondon, E.V. Produção de biomassa e crescimento de árvores de Schizolobium amazonicum (Huber) Ducke sob diferentes espaçamentos na região de mata. Rev. Árvore 2002, 26, 573-576. [CrossRef]

20. Vieira, C.R.; Weber, O.L.; Scaramuzza, J.F. Ash content, carbon and C/N ratio in paricá in function of NPK fertilization. Anais Acad. Bras. Ciências 2018, 90, 333-341. [CrossRef]

21. De Souza, P.R.; do Carmo Silva, B.; Callegari, D.M.; Lobato, E.M.S.G.; da Silva Lobato, A.K. Boron fertilization in Paricá seedlings mitigates negative effects of water deficit. Científica 2020, 48, 264-270. [CrossRef]

22. Oliveira, A.B. Indústria de celulose e o avanço da silvicultura do eucalipto na fronteira agrícola da Amazônia maranhense. Geosul 2019, 34, 301-327. [CrossRef]

23. De Souza Santiago, T.; Damasceno, L.J.; de Cinque Mariano, D.; Ebling, Â.A.; de Oliveira Neto, C.F.; Okumura, R.S. Substratos e doses de fertilizantes de liberação lenta no crescimento e qualidade de Mudas de Paricá. Rev. Agronegócio Meio Ambiente 2021, 14, 1-17. [CrossRef]

24. Caione, G.; Lange, A.; Schoninger, E.L. Crescimento de mudas de Schizolobium amazonicum (Huber ex Ducke) em substrato fertilizado com nitrogênio, fósforo e potássio. Sci. For. 2012, 40, 213-221.

25. Carvalho, A.; Bergamin, A.; Evaristo, A.; Neves, A.; Carmo, C.; Junior, J.G. Initial growth of 'paricá' (Schizolobium amazonicum) seedlings under different nitrogen doses. Nativa 2016, 4, 112-115. [CrossRef]

26. Brito, V.N.; Tellechea, F.R.F.; Heitor, L.C.; Freitas, M.S.M.; Martins, M.A. Fungos micorrízicos arbusculares e adubação fosfatada na produção de mudas de paricá. Ciência Florest. 2017, 27, 485. [CrossRef]

27. Pedroso, A.J.S.; Ruivo, M.D.L.P.; Piccinin, J.L.; Okumura, R.S.; Birani, S.M.; da Silva Júnior, M.L.; de Melo, V.S.; da Rocha Costa, A.; de Albuquerque, M.P. Chemical attributes of Oxisol under different tillage systems in Northeast of Par. Afr. J. Agric. Res. 2016, 11, 4947-4952. [CrossRef]

28. Pesini, F.; Rosa, D.P.; Santos, C.C.; Fincatto, D.; Pagnussat, L.; Bruinsma, M.L. Uso de subsolador como técnica de melhoria física de um solo sob sistema plantio direto em sertão (RS). RAMVI 2014, 1, 1-11.

29. Magalhães, W.D.A.; Freddi, O.D.S.; Lange, A.; Wruck, F.J.; da Silva, W.M.; Soares, M.B. Physical-hydraulic soil attributes in an integrated production system with different "paricá" forest component arrangements. Pesqui. Agropecuária Bras. 2018, 53, 351-360. [CrossRef]

30. Paul, C.; Weber, M. Effects of planting food crops on survival and early growth of timber trees in eastern Panama. New For. 2015, 47, 53-72. [CrossRef]

31. Sales, A. Análise Técnica e Econômica do Cultivo de Paricá em Sistema Agrissilvicultural. Ph.D. Dissertation, Universidade Federal de Viçosa, Viçosa, Brazil, 2018.

32. Siviero, M.A.; Motta, A.M.; Lima, D.D.S.; Birolli, R.R.; Huh, S.Y.; Santinoni, I.A.; Murate, L.S.; de Castro, C.M.A.; Miyauchi, M.Y.H.; Zangaro, W.; et al. Interaction among $\mathrm{N}$-fixing bacteria and AM fungi in Amazonian legume tree (Schizolobium amazonicum) in field conditions. Appl. Soil Ecol. 2008, 39, 144-152. [CrossRef]

33. Nuñez, J.A.D.; Muñoz, D.; González, R.P.; Grau, J.M.; Artero, F.; Anriquez, A.; Albanesi, A. Effects of inoculation with Azospirillum brasilense on the quality of prosopis juliflora seedlings. For. Syst. 2012, 21, 364-372.

34. Yang, G.; Liu, N.; Lu, W.; Wang, S.; Kan, H.; Zhang, Y.; Xu, L.; Chen, Y. The interaction between arbuscular mycorrhizal fungi and soil phosphorus availability influences plant community productivity and ecosystem stability. J. Ecol. 2014, 102, 1072-1082. [CrossRef]

35. Gómez-Romero, M.; Lindig-Cisneros, R.; Villegas, J. Performance of two valuable species, Pinus pseudostrobus and Eysenhardtia polystachya, in a low fertility soil mediated by mycorrhizal fungi and fertilization. Agrofor. Syst. 2019, 93, 2027-2036. [CrossRef]

36. Monteoliva, S.E.; Villegas, M.S.; Achinelli, F.G. Short-term and long-term effects of weed control and fertilization on growth and wood anatomy of a Populus deltoides clone. For. Syst. 2015, 24, 1-5. [CrossRef]

37. Gassibe, P.V.; Oria-De-Rueda, J.A.; Santos-Del-Blanco, L.; Martín-Pinto, P. The effects of fire severity on ectomycorrhizal colonization and morphometric features in Pinus pinaster Ait. seedlings. For. Syst. 2016, 25, 1-16. [CrossRef]

38. Liu, C.; Jin, Y.; Liu, C.; Tang, J.; Wang, Q.; Xu, M. Phosphorous fractions in soils of rubber-based agroforestry systems: Influence of season, management and stand age. Sci. Total Environ. 2018, 616-617, 1576-1588. [CrossRef]

39. Dos Reis, S.M.; Talamini, E.; Neto, P.J.D.S.; Augusto, S.G.; de Melo, A.C.G.; Dewes, H. Growth and yield of mahogany wood in cocoa-based agroforestry systems of two soil types in the Brazilian Amazon. Agrofor. Syst. 2018, 93, 2163-2172. [CrossRef] 
40. Veloso, H.P.; Rangel-Filho, A.L.R.; Lima, J.C.A. Classificação da Vegetação Brasileira, Adaptada a Um Sistema Universal; Instituto Brasileiro de Geografia e Estatística (IBGE): Rio de Janeiro, Brazil, 1991; ISBN 978-85-240-0384-4.

41. Instituto Brasileiro de Geografia e Estatística (IBGE). Mapa de Vegetação Do Brasil, 1st ed.; Instituto Brasileiro de Geografia e Estatística (IBGE): Rio de Janeiro, Brazil, 2004.

42. Empresa Brasileira de Pesquisa Agropecuária (EMBRAPA). Sistema Brasileiro de Classificação de Solos, 3rd ed.; Empresa Brasileira de Pesquisa Agropecuária (EMBRAPA): Brasilia, Brazil, 2018.

43. INMET. I.N.D.M.-Sistema de Suporte à Decisão Na Agropecuária: Balanço Hídrico. 2021. Available online: http:/ / sisdagro. inmet.gov.br/sisdagro/app/monitoramento/bhs (accessed on 15 February 2021).

44. Empresa Brasileira de Pesquisa Agropecuária (EMBRAPA). Manual de Métodos de Análises Do Solo, 3rd ed.; Empresa Brasileira de Pesquisa Agropecuária (EMBRAPA): Brasilia, Brazil, 2017.

45. Tomé, M.M.B.B.T. Modelagem Em Recursos Naturais; Lisboa, Portugal. 2003. Available online: http://www.isa.utl.pt/def/ download/curriculo/cv_margarida_tome.pdf (accessed on 30 August 2019).

46. StataCorp LP. Stata Statistical Software; StataCorp LP: Collge Station, TX, USA, 2021.

47. Campos, J.C.C.; Leite, H.G. Mensuração Florestal: Perguntas e Respostas, 5th ed.; Editora UFV: Viçosa, Brazil, 2017.

48. Schumacher, F.X.; Hall, F.S. Logarithmic expression of timber-tree volume. J. Agric. Res. 1933, 47, 719-734.

49. Kvalseth, T.O. Cautionary note about R 2. Am. Stat. 1985, 39, 279. [CrossRef]

50. Sánchez-González, M.; del Río, M.; Cañellas, I.; Montero, G. Distance independent tree diameter growth model for cork oak stands. For. Ecol. Manag. 2006, 225, 262-270. [CrossRef]

51. Schneider, P.R. Análise de Regressão Aplicada à Engenharia Florestal; Universidade Federal de Santa Maria (UFSM): Santa Maria, Brazil, 1998.

52. Santos, A.C.S.; Fardin, L.P.; de Oliveira Neto, R.R. Teste de Hipótese em Análise de Regressão, 1st ed.; Novas Edições Acadêmicas: Chisinau, Moldova, 2017; ISBN 978-3-330-99856-8.

53. Miranda, D.L.C.; Amorim, P.C.B.; Silva, F.; Lisboa, G.S.; Condé, T.M.; da Silva, C.S. Growth and production of paricá wood in two plantations in the north of Mato Grosso, Brazil. Nativa 2016, 4, 199-205. [CrossRef]

54. Santos, P.R. Crescimento e Produção de Plantios de Paricá (Schizolobium amazonicum Huber Ex. Ducke) Sob Diferentes Espaçamentos. Ph.D. Thesis, Universidade Federal do Espiríto Santo, Jerônimo Monteiro, Brazil, 2012.

55. Medeiros, R.A.; Paiva, H.N.; Leite, H.G.; Oliveira Neto, S.N.; Vendrúscolo, D.G.S.; Silva, F.T. Análise silvicultural e econômica de plantios clonais e seminais de Tectona grandis L.f. em sistema taungya. Rev. Árvore 2015, 39, 893-903. [CrossRef]

56. Modes, K.; Júnior, G.B.; Santos, L.; Bento, A.; Vivian, M.A. Rendimento em laminação da madeira de Schizolobium amazonicum em torno desfolhador do tipo tracionado. Rev. Ciência Madeira-RCM 2014, 5, 151-157. [CrossRef]

57. Hoffamann, R.; Silva, G.; Chichorro, J.; Ferreira, R.; Vescovi, L.; Zaneti, L. Caracterização dendrométrica de plantios de paricá (Schizolobium amazonicum Huber ex. Ducke) na região de Paragominas, PA. Rev. Bras. Ciências Agrárias Braz. J. Agric. Sci. 2011, 6, 675-684. [CrossRef]

58. Schwartz, G.; Pereira, P.C.; Siviero, M.A.; Pereira, J.F.; Ruschel, A.R.; Yared, J.A. Enrichment planting in logging gaps with Schizolobium parahyba var. amazonicum (Huber ex Ducke) Barneby: A financially profitable alternative for degraded tropical forests in the Amazon. For. Ecol. Manag. 2017, 390, 166-172. [CrossRef]

59. Nadeem, S.M.; Ahmad, M.; Zahir, Z.A.; Javaid, A.; Ashraf, M. The role of mycorrhizae and plant growth promoting rhizobacteria (PGPR) in improving crop productivity under stressful environments. Biotechnol. Adv. 2014, 32, 429-448. [CrossRef] [PubMed]

60. Gonçalves, A.; Pontes, A.; Paula, M.; Ferreira, P.; Coelho de Vasconcellos, R.; Fonseca, K. Avaliação do perfil econômico de sistemas agroflorestais nos assentamentos dos trabalhadores rurais expedito ribeiro e abril vermelho, município de Santa Bárbara-PA. Rev. Espac. 2017, 38, 1-10.

61. Terra, D.L.C.V.; de Andrade, V.C.L.; Freitas, B.C. Identidade de modelos volumétrico e de afilamento para Corymbia citriodora. Adv. For. Sci. 2018, 5, 269-274. [CrossRef] 